\title{
Presence of Cholinesterase-rich Nerve Fibers Around the Apocrine Sweat Glands of Japanese Axilla
}

\author{
by \\ Kenjiro Yasuda, Haruo Machida and Toshio Suzuki \\ Department of Anatomy, School of Medicine, Keio University \\ Shinjuku, Tokyo, Japan \\ (Director: Prof. Dr. T. Taniguchi)
}

The distribution of cholinesterase in the human skin has been studied by several investigators, with particular attention to the nerve fibers around the sweat gland ( $\mathrm{H} \mathrm{urley}, \mathrm{Shelly}$ and $\mathrm{K}$ oell e, 1953, Hell man n, 1955, and Montag na and Ellis, 1958). No cholinesterase-positive nerve fibers have been found around the apocrine sweat gland by these investigators, even though a physiological examination revealed definite apocrine responses with acetylcholine and mecholyl (A oki, 1962). On the contrary A a vik (1955), A raki et al (1960) and Montagna and Ellis (1960) have reported the presence of cholinesterase-rich nerve fibers along the apocrine secretory coils of Caucasians, Japanese and Negroes respectively, The main subject of this paper deals with the relationship between the presence of cholinesterase around the apocrine glands and of some other enzymes in the secretory coils. This paper also deals with the distribution pattern of phosphorylase, non-specific esterases and alkaline phosphatase, which is a characteristic of the apocrine glands that are surrounded by nerves containing cholinesterase.

\section{Materials and Methods}

Frozen sections, about $15 \mu$ to $20 \mu$ in thickness, of axillary skin from 10 young Japanese men and women, from whom the osmidrotic area was surgically removed, were examined by histochemical staining methods for cholinesterase ( $\mathrm{K}$ o e l l e and Frie de $\mathrm{n} \mathrm{wald,1949),}$ alkaline phosphatase (Gomori, 1952), non-specific esterases ( $\mathrm{P} \mathrm{e}$ arse, 1953), phosphorylase ( $\mathrm{Takeuchi}$ and $\mathrm{Kuriaki}, 1955)$, succinic dehydrogenase ( $F$ a r ber and L o u viere, 1956), cytochrome 
oxidase (B u r s to n e, 1959) and for monoamine oxidase (G I e n n e r et al, 1957).

\section{Observations}

In all the specimens examined, cholinesterase-rich nerve fibers were encountered around the apocrine gland. There is a wide range of variation, from one person to another, in the number of glands which are surrounded by cholinesterase-positive fibers. In some individuals, the fibers are rarely found in the neighbourhood of the apocrine glands. Even in a single specimen, some of the fibers around the glands are almost nonreactive, while the adjacent glands are wrapped by prominent cholinesterase-positive nerve fibers. The number or the density of the fibers are variable, depending upon each individual gland. The network of the fibers is usually less dense than that around the eccrine sweat gland (Fig. 1 and 2), though some exceptional glands have glomerated nets around them. Most of the fibers come in contact with the gland in a few spiral rows along the longitudinal axis of the gland; a few fibers take a circular course around the secretory coil. Specifically, the fibers tend to run parallel to the longitudinal axis of the myoepithelial cells. There is an appreciable difference in the arrangement of the cholinesterase-positive fibers between apocrine and eccrine glands; the fibers form a thick network around the eccrine gland taking both a longitudinal and circular course around the secretory coil. The density of the network, the course of the fibers in relation to the course of the secretory coil, and the variation of the number of fibers around individual gland are the major differences between apocrine and eccrine glands. The eccrine gland is surrounded by fibers that form a dense network, and take many different directions around the secretory coil, and are relatively constant in number in each gland. The occasional fibers around the apocrine gland communicate with the network around the eccrine gland that is located close to the apocrine gland. There are several dots, which are also reactive to cholinesterase, found in the network around the apocrine gland (Fig. 5). The diameter of a dot is slightly larger than that of the nerve fibers. This feature is not a specific characteristic of the apocrine gland, being also visible around the eccrine gland. This is not found in either the myoepithelial cells, or in the picture of the cross section of the nerve fibers. It is supposed that the dot represents a diverging point of a thick nerve fiber into a 
thinner order.

There are some characteristic patters of the distribution of other enzymes in the secretory cells of the apocrine gland surrounded be cholinesterase-rich nerve fibers. Generally, phosphorylase is prominent in the light cell of the eccrine gland and is not found in the human apocrine gland as $\mathrm{Yasuda}$ et al (1958) and Ellis and Montagna (1958) have reported. It is worthy of note that the spocrine gland abounds in phosphorylase activity in the specimens in which cholinesterase-rich fibers are found around the apocrine gland (Fig. 3). More apocrine glands are reactive to phosphorylase than those with cholinesterase-rich fibers around them; at least the glands with cholinesterase-positive fibers always had a positive phosphorylase reaction in the cytoplasm. The phosphorylase appears as coarse granules throughout the cytoplasm, showing a negative image in the nuclei and in the myoepithelial cells. Another feature of the characteristic distribution of phosphorylase is the occurrence of a considerable amount of reaction in non-typical cells and in myoepithelial cells. The non-typical cell "A" (Y a s u a, 1959) resembles the myoepithelial cells in both appearance and location, but also abounds in glycogen, unlike the myoepithelial cells. In general, it occurs less frequently in the apocrine secretory coil than confirmed in the specimens reported in this paper. It is shown that these non-typical cells are reactive to phosphorylase, being contrasted with the negative activity in the regular myoepithelial cells. As an exception, the myoepithelial cells, genereally nonreactive, present strong activity in some, but not all of the secretory coils of the apocrine glands surrounded by cholinesterase-positive nerve fibers (Fig. 6). They are apparently typical myoepithelial cells and are easily distinguishable from the non-typical cells mentioned above. The peculiar distribution of phosphorylase present in the specimens examined in this work has important meaning, when this enzyme appears together with cholinesterase; both enzymes are invisible in the regular apocrine gland of human axilla.

Non-specific esterases, including $\alpha$-naphthol esterase and ASacetate esterase, are seen moderately in the cytoplasm as $\mathrm{Mon}$ $\mathrm{t}$ a $\mathrm{g} \mathrm{n}$ a (1955) reported. In addition to this feature, there are several specific cells or cell groups which are intensely reactive to these enzymes, intercalated between regular secretory cells (Fig. 7).

The apocrine glands are generelly free of alkaline phosphatase demonstrated by the azo dye method (Fig. 8). There are also some unusual locations where this enzyme is found in the apocrine gland. 
The myoepithelial cells, especially the myofibrils, demonstrate moderate activity, with no reaction in the secretory cells (Fig. 9). Another pattern encountered is the remarkable activity in both myoepithelial cells and secretory cells (Fig. 10).

As far as the distribution of cytochrome oxidase, monoamine oxidase and succinic dehydrogenase is concerned, no fundamental differences were observed between regular human apocrine glands and those examined in this study.

\section{Discussion}

The results obtained as presented in this paper resolve themselves into the following two major points:

I. Cholinesterase-rich nerve fibers were encountered around the apocrine secretory coils in the axilla of 10 Japanese.

II. The distribution pattern of the following enzyme is quite characteristic in some of the specimens, in which the apocrine glands are surrounded by cholinesterase-containing nerve fibers. However, the peculiar location of such enzymes does not necessarily occur together, each with the other enzyme; a specific gland did not always have positive results, at all times, when all the enzymes were examined.

a) The secretory cells of the apocrine glands are reactive to phosphorylase, while the myoepithelial cells of such glands are nonreactive.

b) The number of the non-specific cells intercalated in the apocrine secretory portion is far more than those in the regular axillary apocrine gland. The non-specific cells abound in phosphorylase activity.

c) The myoepithelial cells of some of the secretory coils are intensely reactive to phosphorylase, while the secretory cells of such coils are free of this enzyme.

d) There are several cells or cell groups showing stronger activity of non-specific esterases than the surrounding regular apocrine secretory cells which have a moderate reaction.

e) Alkaline phosphatase is found in the myoepithelial cells, and also in the occasional secretory cells.

It is of deep significance that these characteristic exceptions found in the distribution of enzymes are integrated in the human axilla. Some of the unusual patterns, of each enzyme, may represent a certain condition of function of the sweat gland, while other 
features may indicate the residue or reappearance of the conditions found in the early developmental stages, both in phylogeny and ontogeny. Before discussing the physiological and biological significance of the histochemical results, it is important to look at the characteristic distribution of some definite enzymes from the standpoint of the ontogenetic and phylogenetic development of the sweat glands. The cholinesterase-containing nerve fibers are found around the sweat glands of the following primates;

\begin{tabular}{|c|c|c|c|c|}
\hline \multirow[b]{2}{*}{ Name of primates } & \multicolumn{2}{|c|}{ Body surface } & \multirow{2}{*}{$\begin{array}{c}\text { Special } \\
\text { glands }\end{array}$} & \multirow{2}{*}{$\begin{array}{c}\text { Type of } \\
\text { sweat gland } \\
\text { in general } \\
\text { body surface, } \\
\text { except in } \\
\text { palm and sole }\end{array}$} \\
\hline & $\begin{array}{c}\text { General } \\
\text { region }\end{array}$ & Special region & & \\
\hline $\begin{array}{l}\text { Nycticebus caucang } \\
(\mathrm{M} \text { o n t a } \mathrm{g} \text { a, Y a s u d a } \\
\text { and E Il i s, 1961) }\end{array}$ & + & $\begin{array}{l}\text { lip } \\
\text { genital area }+ \\
\text { perianal area }+\end{array}$ & $\begin{array}{l}\text { brachial } \\
\text { organ } \\
\quad+\end{array}$ & Apocrine \\
\hline $\begin{array}{l}\text { Galago senegalensis } \\
\text { (Ya u d a, A o k i and } \\
\text { Montag a, 1961) }\end{array}$ & - & $\begin{array}{ll}\text { lid } & + \\
\text { vulva } & + \\
\text { perianal area } & +\end{array}$ & - & Apocrine \\
\hline $\begin{array}{l}\text { Perodicticus potto } \\
\text { (M o n t a g a and E } 11 \mathrm{is} \text {, } \\
\text { 1959) }\end{array}$ & - & - & $\begin{array}{l}\text { inguinal } \\
\text { gland } \\
+\end{array}$ & Apocrine \\
\hline $\begin{array}{l}\text { Loris tardigradus } \\
\quad(\mathrm{M} \text { on t a g n a and E } 11 \mathrm{is} \text {, } \\
1961)\end{array}$ & - & - & $\begin{array}{l}\text { brachial } \\
\text { gland } \\
+\end{array}$ & Apocrine \\
\hline $\begin{array}{l}\text { Galago crassicaudatus } \\
\text { (M o n t a g n a and } \mathrm{Y} \mathrm{u} \mathrm{n,} \\
\text { 1962) }\end{array}$ & + & - & - & Apocrine \\
\hline $\begin{array}{l}\text { Lemur catta } \\
(\mathrm{M} \text { o n t a g n a and Y u n, } \\
1962)\end{array}$ & - & - & $\begin{array}{l}\text { antibrachial } \\
\text { organ } \\
+\end{array}$ & $\begin{array}{l}\text { Apocrine } \\
\text { Eccrine }\end{array}$ \\
\hline $\begin{array}{l}\text { Macacus fuscata fuscata } \\
\quad(\mathrm{S} \mathrm{u} 2 \mathrm{u} \mathrm{k} \mathrm{i,} \mathrm{1962)}\end{array}$ & - & $\begin{array}{l}\text { lid } \\
\text { perianal area }+\end{array}$ & - & $\begin{array}{l}\text { Apocrine } \\
\text { Eccrine }\end{array}$ \\
\hline $\begin{array}{l}\text { Macacus cyclopsis } \\
\text { (M a c h i d a, 1962) }\end{array}$ & - & $\begin{array}{l}\text { lid } \\
\text { perianal area }+\end{array}$ & - & $\begin{array}{l}\text { Apocrine } \\
\text { Eccrine }\end{array}$ \\
\hline $\begin{array}{l}\text { Papio doguera } \\
\text { (M o n t a g n a and } \mathrm{Yu} \mathrm{n}, \\
\text { 1962) }\end{array}$ & - & - & - & $\begin{array}{l}\text { Apocrine } \\
\text { Eccrine }\end{array}$ \\
\hline $\begin{array}{l}\text { Hylobates hoolock } \\
\text { (Pa r a k a l, Montag na } \\
\text { and Ellis, 1962) }\end{array}$ & - & - & - & $\begin{array}{l}\text { Apocrine } \\
\text { Eccrine }\end{array}$ \\
\hline
\end{tabular}

Namely, in the primates, the cholinesterase-positive fibers around the apocrine glands appear sparsely in the general body surface, 
which is provided with apocrine-type sweat glands, but with no corresponding apocrine glands in the human skin. There is a moderate amount of nerve fibers around the apocrine glands in the lip, lid, genital area and the perianal region, where the apocrine glands are found together with the eccrine glands in human skin. The inguinal, brachial and antibrachial glands which are characteristic of each animal but not found in the human skin, are surrounded by a numerous number of fibers. Moreover, the sweat glands in the general body surface are supplied, more or less, with cholinesterase-positive nerve fibers, in those primates which have only apocrine-type sweat glands in the skin. In contrast, there are scarcely any fibers containing cholinesterase around the apocrine glands of other primates that are provided with both eccrine and apocrine glands in the skin. It has been temporarily concluded that the distribution pattern of cholinesterase-rich nerve fibers around the apocrine gland of the human axilla bear a resemblance to that of several glands, i.e. inguinal, brachial and antibrachial glands, and those found in specific body regions, i. e. the genital area, the perianal region and the eyelid, of the lower primates. In addition, since the fibers are less often found in the higher primates, than in the lower, it must be assumed that the cholinesterase-rich fibers tend to disappear with phylogenetical ascendence, and that the presence of these fibers around human apocrine glands may suggest the residue or revival of the pattern of the lower phylogenetical stages.

During the course of embryonic development, the cholinesteraserich fibers come in contact with the primordia of the apocrine glands of the axilla, the perianal area and the eyelid in the 8th to 10th foetal month (M a c h i a, 1962), though it is uncertain whether or not this contact of fibers to the gland denotes real innervation. Therefore, the cholinesterase-rich fibers which appear during both phylogenetical and ontogenetical development produce a reaction that will give rise to a cholinesterase-negative fibers in some future stage of the development. Furthermore, since the number of the cholinesterase-positive fibers did not increase after the injection of mecholyl or pilocarpine, and the injection of cholinergic or adrenergic reagents could not turn cholinesterase-negative fibers into positive (M a c hid a, 1963), the presence of cholinesterase-positive fibers represents the exceptional residue of some primitive condition, rather than a functional aspect.

Concerning the phosphorylase activity in the sweat gland, 
Yas uda et al (1958) concluded that the presence of this enzyme is characteristic of the eccrine sweat gland, because this enzyme distributes itself exclusively in the basal light cell of the eccrine gland, and no activity is encountered in the superficial cell or dark cell of the eccrine gland and in the secretory cells of the apocrine glands. E 11 is and Montag na (1958) reported that the presence of this enzyme in the human eccrine gland might be peculiar to humans. Unfortunately, the two opinions become controversial, and open to question, since the apocrine glands of the lower primates have been found to be reactive to phosphorylase. In the primates, the phosphorylase reaction is positive in the apocrine secretory cells of the general body surface of Loris tardigradus, Nycticebus caucang, Galago senegalensis and Galago crassicaudatus, and in the brachial organ (Loris tardigradus and Nycticebus caucang) and antibrachial organ (Lemur catta). The activity of phosphorylase was seen exclusively in the myoepithelial cells of the apocrine gland of the general body surface of Papio doguera, Hylobates hoolock, Macacus fuscata fuscata and Macacus cyclopsis; these animals have characteristic features being provided with both eccrine and apocrine sweat gland in the general body surface. One exception is Lemur catta, which have phosphorylase activity only in the myoepithelial cells of the antibrachial organ, and nothing in those of the apocrine glands in the general body surface, which is covered by both eccrine and apocrine sweat glands. Therefore, the phosphorylase activity in the apocrine glands occurs in the secretory cells of the lower primates, and with phylogenetical ascendence, the activity confines itself in the myoepithelial cells, which loose phosphorylase eventually in due course of further ascendence. In the development of human embryos, phosphorylase reaction is positive in the anlagen of the apocrine gland from the 4th to 8 th foetal month (M a c ida, 1962), and gradually decreases in further development, but remaines positive in the myoepithelial cells of a 4year-old child (Montagna, 1949). The phosphorylase reaction increased slightly, but substantially by the injection of mecholyl ( $\mathrm{M} \mathrm{achida}, 1963$ ), and did not turn positive in the negative area of the control sections. Briefly, the pattern of an exceptional appearance of phosphorylase in the apocrine gland is due to the integration, or the residue of several features concerned with the distribution of the enzyme in the course of both phylogeny and ontogeny, rather than a distinct part of a functional condition of secretory activity in the apocrine gland. 
The non-specific esterase is moderately reactive in the apocrine sweat glands of the primates, with the exception of Lemur catta which has a weak reaction in the antibrachial organ and of Hylobates hoolock, which has substrate specificity against tween esterase, $\alpha$-naphthol esterase and AS-acetate esterase, and also has regional differences in their distribution. Consequently, no such cell as found in the human axilla was recognized in those primates which have previously been reported. These kinds of cells are also invisible during the development of the human embryo. In contrast, esterase reaction increases by the injection of poisons for the autonomic nerve systems (M a c hida, 1963). The presence of some kinds of cells which are strongly reactive to esterases implies a hyper-functional condition of some particular or individual cell which is intercalated between regular secretory cells; the presence of these cells is recognizable neither in phylogeny nor ontogeny.

The activity of alkaline phosphatase occurs mostly in the apical portion of the secretory cells of the apocrine gland in the general body snrface of the primates, i. e. Galago senegalensis, Lemur catta and Hylobates hoolock. An intense reaction appears in special organs, i. e. the brachial organ of Nycticebus caucang and the antibrachial organ of Lemur catta, and in the apocrine gland of Papio doguera. The myoepithelial cells are strongly reactive in the apocrine glands of the general body surface of Nycticebus caucang and Papio doguera, in those of the special body regions, the lip, eyelid, vulva and perianal region, of Galago senegalensis, and in special glands, the brachial organ of Nycticebus caucang and antibrachial organ of Lemur catta. In the development of the human embryo, no alkaline phosphatase reaction was visible in the primordia of the apocrine sweat gland, except in the central area of the clavated anlagen of 4 th and 5 th month. Due to the fact that the reaction of alkaline phosphatase appears in the course of phylogeney, but not in the ontogeny, and that this enzyme is markedly sensitive to the injection of mecholyl and acetylcholine, the presence of this enzyme in the human apocrine gland suggests that this feature is not characteristic of the primitive glands but is a functional aspect of the secretion of the glandular cells.

Comparing all features, the presence of the cholinesterase-rich nerve fibers around the secretory portion of the apocrine gland, and that of phosphorylase activity in the secretory cells, occuring at the same time in the same gland, constitute the integrated features of patteans which are seen at some periods in the course of both phy- 
logeny and ontogeny. Namely, these feature can be interpretated as a continuation, rivival or residue of the pattern of the primitive periods. On the contrary, the activity of cholinesterase and phosphorylase increases after an injection of poisons for autonomic nerve fibers; even though this data was obtained not in the human skin but in the skin of the experimental dogs. Therefore, regarding the distribution of two enzymes, the functional aspect would be partly overlapped by the primitive features. Furthermore, it is of consequence that the distribution pattern of these two enzymes in the human apocrine gland of the axilla is quite similar to that of the special glands such as the brachial and antibrachial organs of the lower primates; the apocrine glands in the axilla are thought to be also a special kind of gland from the phylogenetical and histochemical point of view. The meaning of the presence of esterase in come particular cells, and alkaline phosphatase in the myoepithelial cells is thought to be of functional rather than of phylogenetical and ontogenetical significance.

\section{Conlusion}

The authors have recognized an appreciable amount of nerve fibers containing acetylcholinesterase, around the secretory coils of the apocrine glands in the axilla of 10 Japanese. The fibers are arranged more coarsely around the apocrine glands than around the eccrine gland, and most of the fibers take a course rather along the longitudinal direction than along the circular direction of the secretory coils. Other glands in individual specimens in which the apocrine glands are surrounded by cholinesterase-rich fibers or identical glands which are wrapped by these fibers, showed some characteristic patterns in the distribution of phosphorylase, non-specific esterase and alkaline phosphatase. These particular feature are not always encountered in the normal axilla, and even in the osmidrotic skin in which the apocrine glands are not provided with cholinesterase-positive fibers. The presence of cholinesterase-rich fibers and positive reaction of phosphorylase in the apocrine glands are the integration of the distribution pattern of these enzymes during the course of phylogenetical and ontogenetical ascendence, and are thought to be the residue or accidental reappearance of functional conditions of primitive periods. In contrast, the presence of various cells which are intensely positive to non-specific esterase, and the strong activity of alkaline phosphatase in the myoepithelial cells 
are suggestive of a functional aspect of the secretory cycle of the individual specimens or glands.

The anthors wish to dedicate this paper to our excellent teacher, Dr. Toratoshi Tan i g c hi, M. D., who gave us a kind help during the course of this work. It is with great regret that he passed away before this paper is published.

\section{References}

A a vi k, O. R. Cholinesterase in human skin. J. Invest. Derm., 24 : 103-106, 1955.

A ok i, T. Stimulation of human axillary apocrine sweat glands by cholinergic agents. J. Invest. Derm., 38 : 41-44, 1962.

A ra ki, M. and Fuji , A. Histochemical studies of the nerve in the sweat glands. Proc. Jap. Histochem Ass., Ist. Annual General Meeting. 1 : 123-127, 1960.

Burstone, M.S. Modification of histochemical techniques for the demonstration of cytochrome oxidase. J. Histochem. Cytochem., 9: 59-65, 1961.

Ellis, R. A. and Montagna, W. Histology and cytochemistry of human skin. $\mathrm{XV}$. Sites of phosphorylase and amylo-1.6 glucosidase activity. J. Histochem. Cytochem., 6: 201-207, 1958.

F a r ber, E. and L o u viere, C. D. Histochemical localization of specific oxidative enzymes. IV. Soluble oxidation-reduction dyes as aids in the histochemical localization of oxidative enzymes with tetrazolium salts. J. Histochem. Cytochem. $4: 347-356,1956$.

Glenner, G. G., Burtner, H. J. and Brown, G. W., Jr. The histochemical demonstration of monoamine oxidase activity by tetrazolium salts. J. Histochem. Cytochem., 5 : 591-600, 1957.

Gomori, G. Microscopic Histochemistry. Principles and Practice. The University of Chicago Press, Chicago, Illinois, 1952.

$\mathrm{H}$ e $11 \mathrm{~m}$ a $\mathrm{n} \mathrm{n}, \mathrm{K}$. Cholinesterase and amine oxidase in the skin: A histochemical investigation. J. Physiol., 129: 454-463, 1955.

$\mathrm{Hurley}, \mathrm{H}$. J., Shelle $\mathrm{S}, \mathrm{W}$. B. and Koelle, G. B. The distribution of cholinesterases in human skin, with special reference to eccrine and apocrine sweat glands. J. Invest. Derm., 21 : 139-147, 1953.

Koelle, G.B. and Frieden wald, J.S. A histochemical method for localizing cholinesterase activity. Proc. Soc. Exp. Biol. Med., 70:617-622, 1949.

$\mathrm{Machida}, \mathrm{H}$. and $\mathrm{Suzuki}, \mathrm{T}$. A histochemical study on the skin of primates. Kaibo. Z. 37 : suppl. 3, 1962.

$\mathrm{Machida}, \mathrm{H}$. and $\mathrm{Suzuki}, \mathrm{T}$. Histochemical study on the skin of human embryos. Kaibo. Z. 38 : suppl. 12, 1963.

$\mathrm{Machida}, \mathrm{H}$. A histochemical study on the sweat glands of dogs, with special reference to the reaction to drugs and thermal stimulation. Kaibo. Z. 38:62, 1963.

Mont a g na, W. Histology and cytochemistry of human skin. IX. The distribution of non-specific esterases. J. Biophys. Biochem. Cytol., 1 : 13-16, 1955.

Montagna, W. and Ellis R. A. The skin of primates. I. The skin of the potto (Perodicticus potto). Am. J. Phys. Anthrop., 17: 137-162, 1959.

Montagna, W. and Ellis R.A. Histology and cytochemistry of human skin. XXI. The nerves around the axillary apocrine glands. Am. J. Phys. Anthrop., 
18: 69-70, 1960.

Montagna, W. and Ellis, R.A. The skin of primates. II. The skin of the slender loris (Loris tardigradus). Am. J. Phys. Anthrop., 18: 19-44, 1960.

Montagna, W., Yasuda, K. and Ellis, R. A. The skin of primates. III. The skin of the slow loris (Nycticebus caucang). Am. J. Phys. Anthrop., 19: 1-22, 1961.

Mont a g a, W. and Yun, J.S. The skin of primates. VII. The skin of the great bushbaby (Galago crassicaudatus). Am. J. Phys. Anthrop., 20 : 149-166, 1962.

Montagna, W. and $\mathrm{Yun}, \mathrm{J}$.S. The skin of primates. VIII. The skin of the anubis baboon (Papio doguera). Am. J. Phys. Anthrop., $20: 131-142,1962$.

$\mathrm{M}$ ontagna, W. and $\mathrm{Yun}, \mathrm{J}$.S. The skin of primates. X. The skin of the ringtailed lemur (Lemur catta). Am. J. Phys. Anthrop., 20 : 95-118, 1962.

Pearse, A.G.E. Histochemistry, Theoretical and Applied. Little Brown and Co., - Boston, 1953.

Parakkal, P., Montagna, w. and Ellis, R. A. The skin of primates. XI. The skin of the white-browed gibbon (Hylobates hoolock). Anat. Rec., 143: 169-178, 1962.

$\mathrm{Suzuki}, \mathrm{T}$. and $\mathrm{Machida}, \mathrm{H}$. Histocheical study on the skin of Macacus fuscata fuscata. Kaibo. Z. 38 : suppl. 11, 1963.

Takeuchi, T. and $\mathrm{Kuriaki}, \mathrm{H}$. Histochemical demonstration of phosphorylase in animal tissues. J. Histochem. Cytochem., 3: 153-160, 1955.

$\mathrm{Y}$ a suda, K., Furus a wa, H. and $\mathrm{Og}$ a t a, N. Histochemical investigation on the phosphorylase in the sweat glands of axilla. Okajimas Folia Anatomica Japonica : 31: 162-169, 1958.

$\mathrm{Y}$ a s u da, K. On the non-typical cells in the axillary sweat gland. Okajimas Folia Anatomica Japonica: 33 : 353-371, 1959.

Yasuda, K., Aoki, T. and Montag a, W. The skin of primates. IV. The skin of the lesser bushbaby (Galago senegalensis). Am. J. Phys. Anthrop., 19: 23-34, 1961 .

\section{Explanation of figures}

Fig. 1. Cholinesterase-rich nerves around the secretory portion of the apocrine sweat gland. The distribution pattern of the fibers is much coarser than those around the eccrine sweat gland. As: Secretory portion of the apocrine sweat gland. $\times 200$

Fig. 2. The fibers run mostly along the longitudinal axis of the gland, forming moderately dense networks in the course. $\times 150$

Fig. 3. Strong phosphorylase activity appears in the secretory cells of the apocrine glands, which are surrounded by the cholinesterase-rich fibers in the adjacent sections. The reaction occurs in the coarse granular form allover the cytoplasm of the secretory cells but not in the myoepithelial cells. As : Secretory portion of the apocrine sweat gland. $\times 400$

Fig. 4. The non-specific cells (nc) contain a moderate amount of phosphorylase, while the light cells of the eccrine gland are rich in enzyme. Es: Eccrine secretory coil. Ed : Sweat duct of the eccrine gland. As : Secretory portion of the apocrine gland. $\times 200$

Fig. 5. In the network of the nerve fibers around the apocrine gland, there are several dots (d) which are larger in the diameter than that of the fiber. 
This is neither characteristic of the apocrine gland nor the figure of the myoepithelial cells. $\times 400$

Fig. 6. The myoepithelial cells (My) of some of the secretory segments of the apocrine gland shows marked activity of phosphorylase reaction. On the contrary, the secretory cells are free of the enzyme. $\times 400$

Fig. 7. Activity of AS-acetate esterase is markedly concentrated in some secretory cells (sc), while the other cells are moderately reactive. $\times 200$

Fig. 8. The alkaline phosphatase activity is almost invisible in the secretory cells of the apocrine gland. The endothelial cells of the capillaries which form the network around the secretory segments are intensely reactive to the reaction. As: Secretory segments of the apocrine sweat gland. $\times 400$

Fig. 9. The myoepithelial cells, mostly the myofibrils, have a good amount of alkaline phosphatase. $\times 400$

Fig. 10 Remarkable reaction of alkaline phosphatase is seen in the myoepithelial cells and in the basal part of the secretory cells of the apocrine sweat gland. $\times 400$ 
Plate I
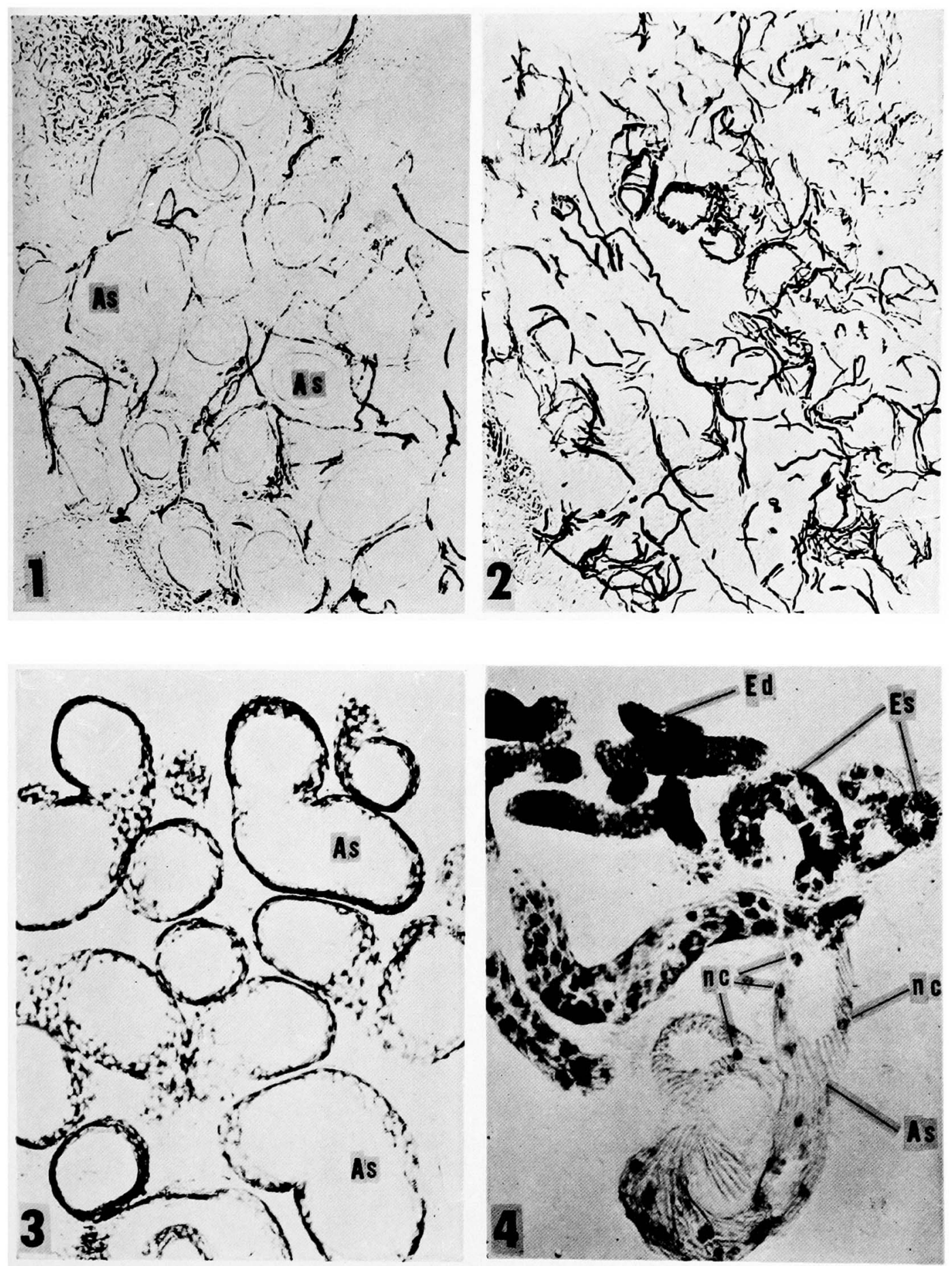

K. Yasuda, H. Machida and T. Suzuki 
Plate II
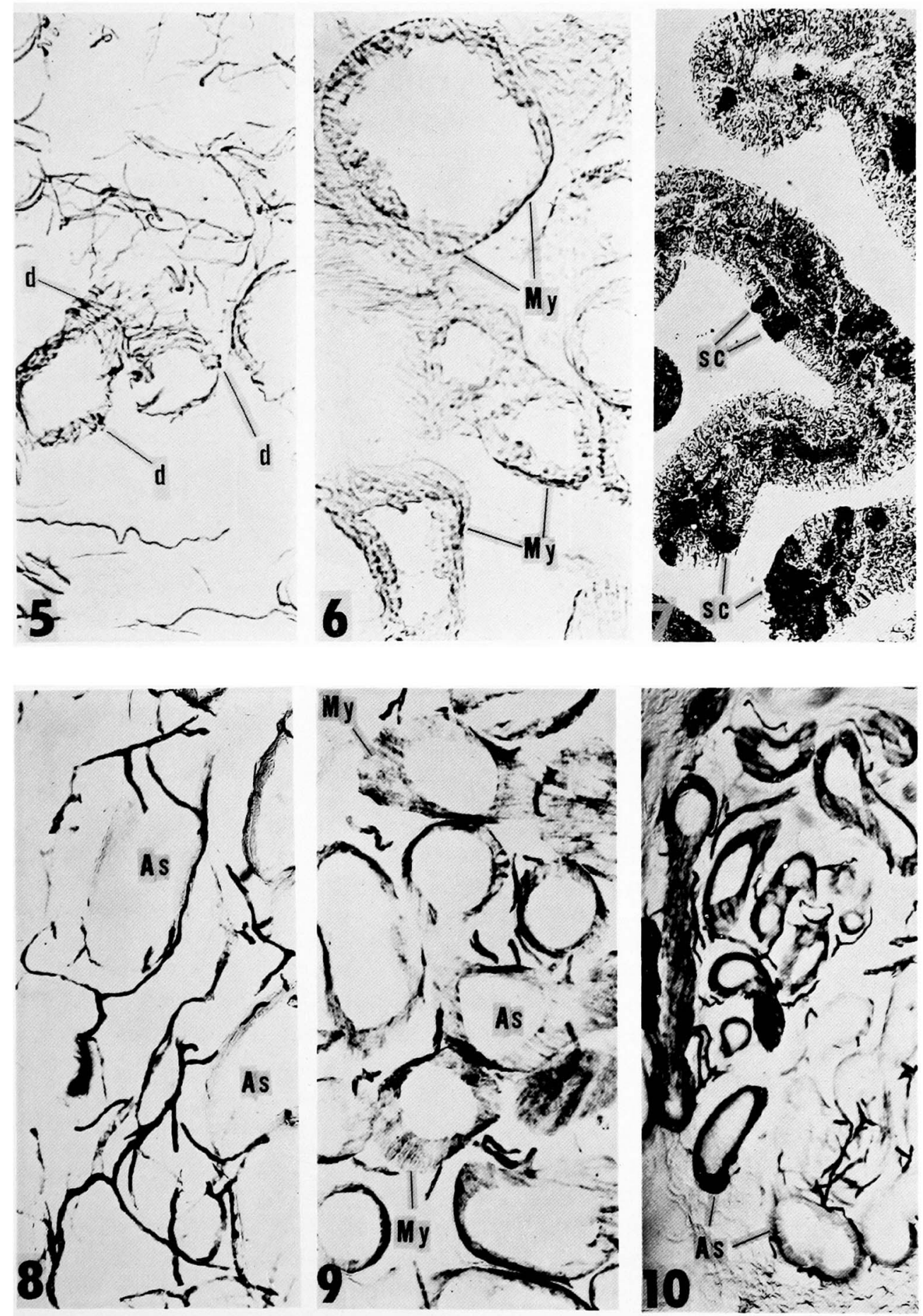

K. Yasuda, H. Machida and T. Suzuki 